\title{
ДОЛГОВАЯ ПОЛИТИКА СУБЪЕКТА ФЕДЕРАЦИИ КАК ФАКТОР ПОВЫШЕНИЯ УСТОЙЧИВОСТИ ФИНАНСОВОЙ СИСТЕМЫ РЕГИОНА
}

\author{
(C) 2021 Гончарук О. В. \\ доктор экономических наук, профессор \\ главный научный сотрудник \\ СПб филиал Финансового университета при Правительстве РФ, Россия, Санкт-Петербург \\ E-mail: OlVGoncharuk@fa.ru \\ (C) 2021 Ахмедов Д. М. \\ студент \\ СПб филиал Финансового университета при Правительстве РФ, Россия, Санкт-Петербург \\ E-mail: den.akhmedov11@mail.ru \\ (c) 2021 Шошин С.H. \\ студент \\ СПб филиал Финансового университета при Правительстве РФ, Россия, Санкт-Петербург \\ E-mail: shoshin_sn@mail.ru
}

В статье рассмотрены теоретические и практические аспекты, связанные с формированием и совершенствованием долговой политики субъектов федерации. Предложены авторские определения долговой политики и долговой устойчивости, проанализированы особенности долговой политики регионов Северо-западного федерального округа, их долговой нагрузки и структуры долгового портфеля, рассмотрены вопросы использования регионами СЗФО субфедеральных облигаций как эффективного долгового инструмента. Дана характеристика долговой устойчивости регионов СЗФО, проанализированы количественные параметры долговой политики Псковской области. Проведен сравнительный анализ долгового портфеля Псковской области и Республики Коми как регионов с разной степенью долговой устойчивости, а также структуры их социально-экономических расходов. В заключении предложены основные направления совершенствования долговой политики субъектов федерации".

Ключевые слова: долговая политика, долговая устойчивость, государственный долг СЗФО, долговые инструменты, бюджетный кредит, государственные ценные бумаги субъекта федерации, государственные гарантии субъекта федерации, кредиты, полученные от кредитных организаций.

Введение. Устойчивость финансовой системы региона является значимым условием обеспечения его социально-экономического развития. Финансовая система, сложная по своему внутреннем составу, может обобщенно быть представлена как совокупность связанных между собой следующих секторов: сектор государственных и муниципальных финансов, финансовый сектор, сектор корпоративных финансов и сектор личных финансов. При этом, как показывает анализ, развитие секторов и их значимость характеризуется различной динамикой. Ведущая роль в российских финансовых системах отводится сектору государственных и му- ниципальных финансов, который представлен, в первую очередь, консолидированным бюджетом и бюджетом субъекта федерации, который, как правило, составляет 80-90\% консолидированного бюджета. На региональный бюджет возложено финансовое обеспечение выполнения функций государственной власти и реализации политики социально-экономического развития, для чего субъекты федерации в соответствии с действующим бюджетным законодательством могут привлекать дополнительные финансовые ресурсы, используя долговые инструменты, которые являются неотъемлемой частью финансовых отношений. При этом задача обеспечения

\footnotetext{
* Статья подготовлена в рамках выполнения научно-исследовательской работы «Обеспечение устойчивости финансовой системы региона: механизм, инструменты, показатели оценки» по государственному заданию в 2021 году
} 
долговой устойчивости бюджета субъекта федерации возложена на региональные органы власти и управления, а институтом, позволяющим выполнять целевые установки, является долговая политика, разработка и реализация которой, с одной стороны, должна соответствовать требованиям нормативных документов [1, ст. 107.1, 2, 3, 4 и др.], а, с другой стороны, должна обеспечивать перспективное социально-экономическое развитие региона.

Долговая политика субъекта федерации: теоретические аспекты. Разработка вопросов, связанных с управлением долгом региона политики субъекта федерации с учетом нормативноправовых требований находится в сфере внимания ученых и специалистов. В целом теоретические и практические аспекты как федеральной, так и региональной долговой политики активно освещаются в научных публикациях с учетом меняющихся внешних и внутренних факторов и условий. Вместе с тем, не все вопросы, касающиеся ее региональных особенностей, получили однозначное раскрытие.

Так, как показал проведенный анализ, одним из дискуссионных вопросов является само понятие долговой политики. Так, например, Волынская О.А., определяет долговую политику как идеологию управления государственным долгом, которая включает в себя тактику его управления и погашения [5, с. 117]. При исследовании критериев долговой оценки Ермакова Е.А. опирается на это же понятие. [6, с. 28]. Очевидно, что долговую политику следует рассматривать не только в краткосрочном, но и в среднесрочном аспекте, что определяет необходимость развития данного определения. По мнению Солдаткина С.Н., данное определение сводится лишь к управлению долгом региона, и долговую политику следует понимать как часть финансовой политики, цель которой сформировать механизм долгового финансирования и обеспечить его функционирование, удерживая долговую нагрузку в допустимых пределах [7, с. 47]. Данное определение, по нашему мнению, отражает понятие эффективности долговой политики, поскольку регионы могут в зависимости от определенных обстоятельств, превышать установленные индикаторы в интересах социальноэкономического развития региона. Х.Дженорио под долговой политикой понимает политику, препятствующую росту задолженности субъекта: «долговое финансирование должно быть разумным, а затраты на его обслуживание не должны препятствовать государственным инвестициям и НИОКР» [8, с. 58]. Разумность - это эмоциональная оценка, поэтому в этом определении практически ценным является указание на такие аспекты долговой политики, как затраты по обслуживанию долга и соотношение общих расходов бюджета и указанных затрат.

Кадзаева И.Т. исследует долговую политику региона как политику, направленную на устранение дефицита бюджета региона [9, с. 158]. Обеспечение профицитности бюджетов субъектов федерации, действительно, является одной из ключевых задач, поставленных перед финансовыми органами регионов, но необходимо отметить, что дефицит регионального бюджета, если заимствования обеспечивают экономический рост в регионе, могут и должны считаться обоснованным явлением.

Кудрявцева С.А., рассматривая государственный долг субъекта федерации, отмечает такие сходства долговой политики региона и государства, как: подчинение целей долговой политики целям социально-экономического развития, наличие многостороннего эффекта, учет внешних и внутренних факторов [10].

Сангинова Л.М. вводит понятие «ответственная и эффективная долговая политика на субфедеральном уровне», понимая под этим «совокупность стратегической цели, направлений, принципов и конкретных мер по привлечению заемных ресурсов, предоставления государственных гарантий, их своевременному и полному обслуживанию» [11, с. 100-101]., определяет критерии эффективной долговой политики, а также формулирует направления повышения ее эффективности [11, с. 104]. Вопросы повышения эффективности долговой политики на примере регионов ДВО рассматривает Солдаткин С.Н., при этом по эффективной государственной региональной долговой политикой предлагает понимать «такую систему управления государственным долгом субъекта РФ, которая позволяет обеспечить осуществление заимствований для финансирования текущего дефицита бюджета и погашения накопленных долговых обязательств с минимальными бюджетными рисками и затратами (расходами)» [12, с. 61-62], определяет признаки эффективной региональной долговой политики: целесообразность заимствований и их оптимальность [12, с. 62].

Королева М.Л., исследуя вопросы современ- 
ного состояния государственного долга субъектов федерации, наряду с тенденцией сокращения долга, отмечает снижение доли ценных бумаг в структуре региональных заимствований [13, с. 185]. На недооцененность субъектов федерации таких форм заимствований как гарантии и облигации также отмечают в своем исследовании Ларина О. И. и Морыженкова Н. В. [14, с. 76].

Таким образом, к основным целям региональной долговой политики, относятся:

- своевременное исполнение бюджетных обязательств;

- финансовое обеспечение социальноэкономического развития региона и потребностей региона через привлечение заемных ресурсов;

- использование различных долговых инструментов (бюджетные кредиты, банковские кредиты, государственные гарантии, государственные ценные бумаги) с целью оптимизации затрат на привлечение заемных ресурсов и обслуживание долга.

По нашему мнению, в число целей долговой политики субъекта федерации целесообразно включить системную цель - обеспечение устойчивости финансовой системы региона, поскольку сектор государственных и муниципальных финансов является для большинства регионов основным в ее структуре, и долговая политика определяет не только бюджетную устойчивость, но и влияет на устойчивость таких региональных секторов как финансовый сектор, сектор корпоративных финансов и сектор личных финансов.

В целом с учетом научно-практических исследований в области долговой политики субъекта федерации, а также подходов к раскрытию особенностей долговой политики, изложенных в утвержденных Минфином России Рекомендациях по проведению субъектами Российской Федерации ответственной заемной/долговой политики и в Основных направлениях государственной долговой политики [3, 4], представляется возможным предложить авторское определение: под долговой политикой субъекта федерации следует понимать деятельность уполномоченных региональных органов власти, направленную путем привлечения ресурсов на рынках капитала на повышение устойчивости финансовой системы региона, обеспечение долговой устойчивости бюджета субъекта федерации, достижение оптимального соотношения рисков и доходности заимствований, повышение кредитного рейтинга региона, а также на развитие механизмов эмиссии субфедеральных облигаций и государственных гарантий в соответствии с социально-экономическими целями территориального развития.

Отметим, что в соответствии с Бюджетным Кодексом РФ, каждый субъект федерации обязан разрабатывать Основные направления долговой политики на очередной финансовый год и плановый период, но при этом вправе сам определять цели и задачи долговой политики и инструменты ее реализации [1, ст. 107.1, п. 11-13].

Степень эффективности долговой политики субъекта федерации характеризуется понятием «долговая устойчивость» и совокупностью ключевых показателей долговой устойчивости. Долговая устойчивость субъекта федерации рассматривается как устойчивость его бюджетной системы. При этом под долговой устойчивостью сектора государственных и муниципальных финансовой системы региона будем понимать исполнение долговых обязательств в установленными в процессе заимствований сроками в соответствии с действующим финансовым законодательством.

В Бюджетном кодексе Российской Федерации определены четыре ключевых показателя долговой нагрузки, позволяющие относить регионом к определенной группе устойчивости (группа заемщиков с высоким уровнем устойчивости, с низким уровнем устойчивости, со средним уровнем устойчивости) [1, ст. 107, п. 1, п. 5]:

- отношение объема государственного долга субъекта к общему объему доходов бюджета без учета безвозмездных поступлений;

- доля платежей по погашению и обслуживанию государственного долга субъекта федерации в общем объеме налоговых и неналоговых доходов субъекта федерации и дотаций из бюджетной системы Российской Федерации;

- доля объема расходов на обслуживание государственного долга субъекта федерации в общем объеме расходов бюджета субъекта;

- доля краткосрочных долговых обязательств в общем объеме долга.

Указанная совокупность показателей не является исчерпывающей. Так, в качестве индикаторов долговой устойчивости также рассматривают показатели, характеризующие относительные показатели такие, как: отношение долга бюджета к ВРП, уровень бюджетного долга 
на душу населения, структура долга по отдельным долговым инструментам. Коречков Ю.В., например, предлагает также использовать показатель отношения темпов прироста долга к прогнозным темпам прироста ВРП [15, с. 76].

Долговая политика и долговая устойчивость регионов СЗФО. Рассмотрим отдельные аспекты и особенности долговой политики и долговой нагрузки в субъектах федерации Северо-западного федерального округа. Мониторинг наличия в регионах Северо-Западного Федерального округа нормативных документов, регламентирующих долговую политику, свидетельствует о том, что всеми регионами этот документ разработан на среднесрочную перспективу [16-26]:

- в 7 субъектах (Санкт-Петербург, Республика Карелия, Новгородская, Мурманская, Калининградская, Архангельская, Вологодская области) действуют «Основные направления долговой политики на 2020 г. и на плановый период 2021 и 2022 годов»;

- в 4 субъектах (Ненецкий АО, Республика Коми, Псковская, Ленинградская области) руководствуются актом «Основные направления долговой политики на 2021 г. и на плановый период 2022 и 2023 годов».

В Таблице 1 приведена за период 20152020 гг. динамика размеров государственного долга и доходов бюджетов субъектов федерации, входящих в состав СЗФО.

Как следует из данных Таблицы 1, доходы регионов СЗФО в 2015-2020 гг. характеризовались ростом, как в целом по СЗФО, так и по отдельным регионам (за исключением Архангельской области в 2016 году и Ненецкого автономного округа в 2020 году), что явилось следствием восстановления темпов промышленного производства и оборотов розничной торговли после кризиса 2015 года, вызванного введением против России международных санкций. При этом стабильность доходов региональных бюджетов в 2020 году была обеспечена за счет трансфертов из федерального бюджета для покрытия выпадающих доходов.

Что касается размера государственного долга регионов СЗФО, то по итогам 2019 года он снизился по всем субъектам федерации, за исключением Санкт-Петербурга, что отражает выполнение регионами целевых установок по повышению качества управления региональными финансами. Динамика размера государственно-

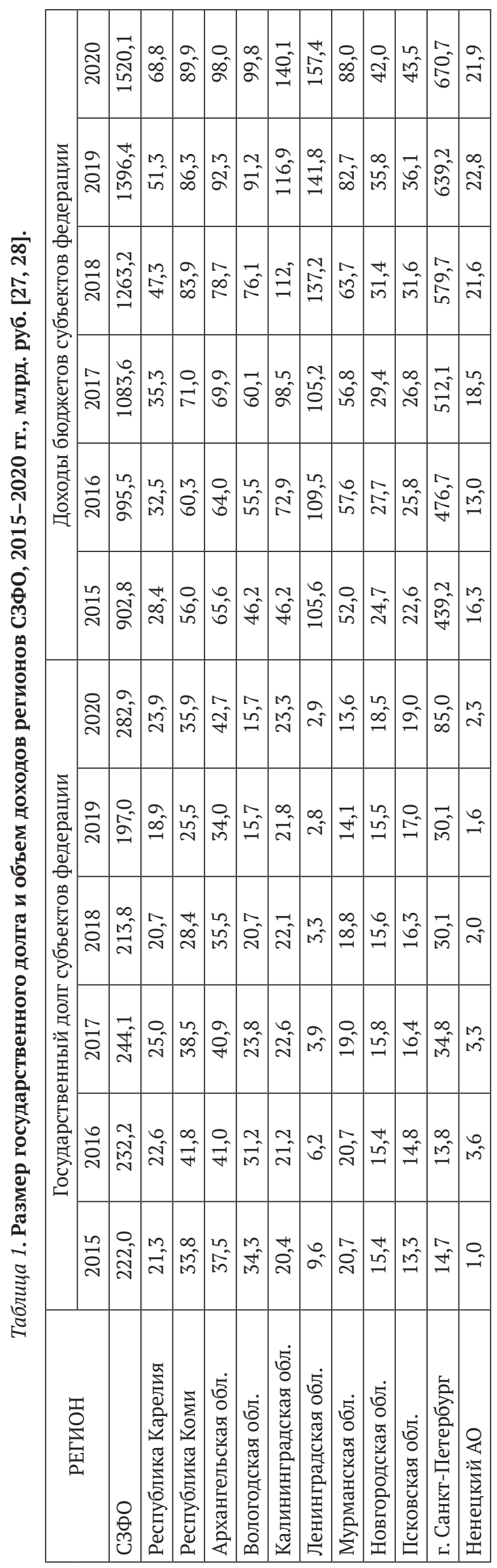


го долга отражает общие количественные показатели, при этом для каждого субъекта федерации размер долга и его динамика определяется в зависимости от используемых долговых инструментов. Так, например, существенное снижение показателей государственного долга было обеспечено в Ленинградской области в 2017 году за счет погашения банковских кредитов на 2,3 млрд. руб.; в Вологодской области в 2019 году за счет погашения бюджетных кредитов на 3,1 млрд. руб.; в Мурманской области в 2020 году за счет погашения банковских кредитов на 1,6 млрд. руб. Рост объемов государственного долга в Санкт-Петербурге в рассматриваемый период обусловлен эмиссией субфедеральных облигаций на сумму 30,1 млрд. руб. в 2017 г. и 30,0 млрд. руб. в 2020 г. Общий рост государственного долга по СЗФО и его регионам в 2020 году был вызван необходимостью поддержки населения и корпоративного сектора вследствие кризисной ситуации из-за эпидемии коронавируса.

Анализ структуры государственного долга за период 2015-2020 гг. показал, что в качестве основных инструментов долговой политики в СЗФО использовались: бюджетные кредиты, кредиты, полученные от кредитных организа- ций, государственные гарантии субъектов федерации, государственные ценные бумаги субъектов федерации (Таблица 2).

Как следует из данных Таблицы 2, в целом за период 2015-2020 гг. наблюдаются тенденции снижения объемов привлеченных средств с использованием таких долговых инструментов как банковские кредиты и государственные гарантии субъектов федерации: объем выданных субъектами федерации гарантий сократился в 2,9 раза, в 1,3 раза сократились объемы банковских кредитов. При этом существенно - в 3,2 раза (главным образом, за счет эмиссии городских облигаций Санкт-Петербурга) - выросли объемы средств, привлеченных субъектами федерации в СЗФО с использованием субфедеральных облигаций. Соответственно изменилась и структура долгового портфеля (Таблица 3, Рисунок 1).

Так, наибольшую долю в структуре долговый инструментов занимают государственные ценные бумаги и кредиты из федерального бюджета, доля которых остается относительно стабильной в общем долговом портфеле и в среднем в рассматриваемый период составляла порядка 40\%. Доля банковских кредитов сократилась на

Таблиц̧а 2. Объем заимствований по долговым инструментам в СЗФО, 2015-2020 гг., в млрд. руб.

\begin{tabular}{|c|c|c|c|c|c|}
\hline Год & $\begin{array}{c}\text { Государственные } \\
\text { ценные бумаги } \\
\text { субъектов федера- } \\
\text { ции }\end{array}$ & $\begin{array}{c}\text { Кредиты, полученные } \\
\text { от кредитных органи- } \\
\text { заций }\end{array}$ & $\begin{array}{c}\text { Государствен- } \\
\text { ные гарантии } \\
\text { субъектов } \\
\text { федерации }\end{array}$ & $\begin{array}{c}\text { Бюджетные } \\
\text { кредиты }\end{array}$ & Общий долг \\
\hline 2015 & 34,0 & 90,0 & 9,6 & 88,4 & 222,0 \\
\hline 2016 & 28,6 & 89,6 & 8,9 & 105,1 & 232,2 \\
\hline 2017 & 60,7 & 80,8 & 5,9 & 96,5 & 244,0 \\
\hline 2018 & 58,5 & 66,8 & 4,2 & 84,2 & 213,7 \\
\hline 2019 & 55,4 & 59,2 & 3,3 & 79,2 & 197,1 \\
\hline 2020 & 108,3 & 68,9 & 3,3 & 102,4 & 282,9 \\
\hline
\end{tabular}

Составлено авторами по: [27].

Таблица 3. Структура долгового портфеля регионов СЗФО в\%, 2015-2020 гг.

\begin{tabular}{|c|c|c|c|c|}
\hline Год & $\begin{array}{c}\text { Государственные цен- } \\
\text { ные бумаги субъектов } \\
\text { федерации }\end{array}$ & $\begin{array}{c}\text { Кредиты, полученные } \\
\text { от кредитных органи- } \\
\text { заций }\end{array}$ & $\begin{array}{c}\text { Государственные } \\
\text { гарантии субъектов } \\
\text { федерации }\end{array}$ & Бюджетные кредиты \\
\hline 2015 & $15,3 \%$ & $40,5 \%$ & $4,3 \%$ & $39,8 \%$ \\
\hline 2016 & $12,3 \%$ & $38,6 \%$ & $3,9 \%$ & $45,2 \%$ \\
\hline 2017 & $24,9 \%$ & $33,1 \%$ & $2,4 \%$ & $39,6 \%$ \\
\hline 2018 & $27,4 \%$ & $31,3 \%$ & $2,0 \%$ & $39,4 \%$ \\
\hline 2019 & $28,1 \%$ & $30,0 \%$ & $1,7 \%$ & $40,2 \%$ \\
\hline 2020 & $38,3 \%$ & $24,3 \%$ & $1,2 \%$ & $36,2 \%$ \\
\hline
\end{tabular}

Составлено авторами по: [27]. 


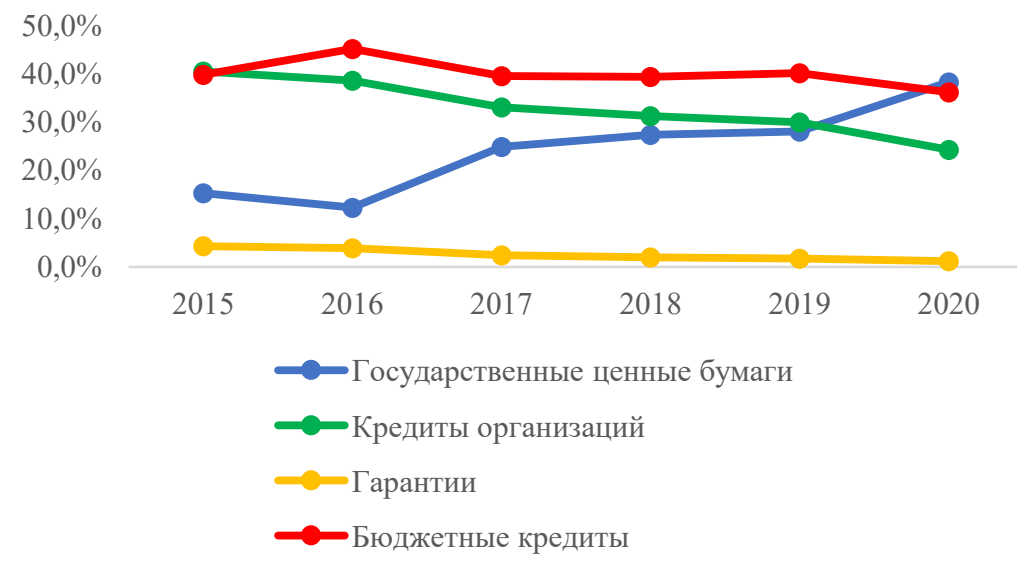

Puc. 1. Динамика структуры долгового портфеля регионов СЗФо,\%, 2015-2020 гг. Составлено авторами по: [27].

16,2\% за счет перераспределения объемов заимствований в пользу такого инструмента, как субфедеральные облигации. Доля государственных гарантий субъектов федерации уменьшилась не только в абсолютном объеме (см. Таблицу 2), но и относительно, и составила в 2020 году только 1,2\% всего долга.

В соответствии с выявленными тенденциями динамики структуры долга регионы СЗФО могут быть разделены на группы, различающиеся по структуре долга:

- группа «А», в состав которой входят регионы с высокой долей субфедеральных облигаций: Санкт-Петербург, Республика Коми, Ненецкий $\mathrm{AO}$

- группа «Б», которая включает в себя регионы с высокой долей федерального кредитования: Республику Карелия, Мурманскую, Новгородскую, Вологодскую, Ленинградскую и Калининградскую области;

- группа «В», в которой представлены регионы Архангельская и Псковская области, которые преимущественно используют такие долговые инструменты, как банковские кредиты и бюджетные кредиты и не используют такой долговой инструмент как субфедеральные облигации.

Изменение структуры долгового портфеля регионов в целом отражает тенденцию развития финансового рынка в Российской Федерации. При этом привлечение финансовых ресурсов в региональный бюджет на основе эмиссии субфедеральных облигаций позволяет [3]: 1) уменьшить зависимость от федерального бюджета при финансировании текущих расходов; 2) минимизировать воздействие внешних форс-мажорных факторов на процесс исполнения бюджета;
3) оптимизировать затраты на привлечение и обслуживание долга в среднесрочной и долгосрочной перспективе.

Вместе с тем, несмотря на рост объемов средств, привлеченных через эмиссию и размещение субфедеральных облигаций, этот инструмент еще недостаточно активно используется субъектами федерации в СЗФО. В рассматриваемый период лидерами по объемам эмиссии среди регионов федерального округа являлись Санкт-Петербург, Республика Коми и Вологодская область; эмитировали облигации в небольших объемах Калининградская область, Республика Карелия и Ненецкий $\mathrm{AO}$; не проводили эмиссию облигаций Архангельская, Ленинградская, Мурманская, Новгородская и Псковская области (Таблица 4), а также все муниципальные образования в СЗФО.

Целесообразность определения в качестве одного из направлений совершенствования долговой политики субъекта федерации выпуск субфедеральных облигаций, определяется тем, что они являются одним из наиболее эффективных долговых инструментов, поскольку обладают следующими преимуществами по сравнению с другими долговым инструментами:

- заимствования осуществляются в соответствии с рыночными параметрами, которые могут быть более выгодными, чем при коммерческом кредитовании. Субфедеральные облигации пользуются повышенным спросом среди крупных фондов, поскольку обладают пониженным риском дефолта, имеют более высокую в сравнении с ОФЗ доходность, являются долговыми инструментами среднесрочного и долгосрочного характера; 
Таблица 4. Объем эмиссии субфедеральных облигаций регионов СЗФО, 2015-2020 гг.

\begin{tabular}{|l|c|c|c|c|c|c|c|}
\hline \multirow{2}{*}{ Субъект СЗФО } & \multicolumn{7}{|c|}{ Объемы эмиссии, млрд. руб. } \\
\cline { 2 - 8 } & 2015 & 2016 & 2017 & 2018 & 2019 & 2020 & Итого \\
\hline Санкт-Петербург & - & - & 30,1 & - & - & 30,0 & 60,1 \\
\hline доля в доходах бюджета, в \% & - & - & 5,9 & - & - & 4,5 & - \\
\hline Республика Карелия & - & 1,03 & 2,0 & 0,1 & - & - & 3,03 \\
\hline доля в доходах бюджета, в \% & - & 3,2 & 5,7 & 0 & - & - & - \\
\hline Республика Коми & 10,1 & 3,1 & 10,0 & - & - & - & 23,2 \\
\hline доля в доходах бюджета, в \% & 18,0 & 5,1 & 14,1 & - & - & - & - \\
\hline Вологодская область & 5,0 & - & 10,0 & - & - & - & 15,0 \\
\hline доля в доходах бюджета, в \% & 10,8 & - & 16,6 & - & - & - & - \\
\hline Калининградская область & - & 1,0 & 1,7 & - & - & - & 2,7 \\
\hline доля в доходах, бюджета, в \% & - & 1,4 & 1,7 & - & - & - & - \\
\hline Ненецкий АО & - & - & 0,5 & 1,4 & - & - & 1,9 \\
\hline доля в доходах бюджета, в \% & - & - & 2,7 & 6,5 & - & - & - \\
\hline
\end{tabular}

Составлено авторами по: [29].

- не предполагается строгая целевая направленность эмиссии, как, например, в случае с федеральными кредитами. Субъект федерации распоряжается привлеченными средствами в соответствии со своими потребностями;

- могут использоваться для рефинансирования банковских кредитов, что повышает эффективность заимствования для регионов. Сроки погашения облигаций длиннее, чем сроки погашения кредитов, а ставки по облигационным займам ниже, чем ставки по банковским кредитам, что в итоге уменьшает риски, связанные с привлечением финансовых ресурсов субъектами федерации;

- предусматривается, как правило, возможность оперативного управления долгом на вторичном рынке путем выкупа облигаций или их досрочного погашения;

- при регулярной эмиссии формируется положительная кредитная история регионаэмитента, что позволяет ему в дальнейшем привлекать финансирование на еще более выгодных условиях.

Высокий текущий спрос на финансовом рынке позволяет регионам успешно проводить размещения облигаций. Так, например, при размещении 27 октября 2020 г. Санкт-Петербургом субфедеральных облигаций объемом 30 млрд. руб. со сроком погашения 30 апреля 2027 года, спрос на них составил 83,3 млрд. руб.

Оценка долговой устойчивости субъектов федерации проводится Министерством финансов России в соответствии со статьей 107.1 Бюджетного кодекса РФ «Оценке долговой устой- чивости субъекта Российской Федерации», в которой установлены индикаторы ключевых показателей, определяющие уровень долговой устойчивости субъектов федерации [1, ст. 107.1, п. 5].

Оценка долговой устойчивости регионов была проведена Министерством финансов Российской Федерации в сентябре 2020 года по итогам 2019 г. в порядке, установленном постановлением Правительства Российской Федерации «Об утверждении Правил проведения оценки долговой устойчивости» от 04.03.2020 № 227 [30]. По ее результатам к группе с высоким уровнем долговой устойчивости из регионов СЗФО были отнесены: Вологодская область, Ленинградская область, Мурманская область, Республика Коми, Санкт-Петербург; к регионам с низким уровнем долговой устойчивости - Псковская область. Остальные регионы СЗФО были отнесены к регионам со средним уровнем долговой устойчивости [31]. Несмотря на значительную долю регионов в СЗФО с высоким уровнем долговой устойчивости, долговую нагрузку субъектов СЗФО можно охарактеризовать как умеренную (Таблица 5).

Как следует из данных Таблицы 5, за оцениваемый период по всем регионам СЗФО доля государственного долга в доходах бюджетов субъектов федерации существенно сократилась. Регионами с низкой долговой нагрузкой являются Ленинградская область и Санкт-Петербург, которые при этом придерживаются различной долговой политики. Отметим, что уровень долговой нагрузки и долговой устойчивости 
Таблицุ 5. Оценка долговой нагрузки бюджетов субъектов СЗФО, 2015-2019 гг.,\%

\begin{tabular}{|c|c|c|c|c|c|c|}
\hline \multirow[b]{2}{*}{ Субъект СЗФО } & \multicolumn{5}{|c|}{ Доля государственного долга в доходах бюджета, в \% } & \multirow{2}{*}{$\begin{array}{c}\text { Уровни дол- } \\
\text { говой устой- } \\
\text { чивости на } \\
1.10 .2020 \text { г. }\end{array}$} \\
\hline & 2015 & 2016 & 2017 & 2018 & 2019 & \\
\hline Архангельская область & 57,2 & 64,0 & 58,6 & 45,2 & 36,8 & средний \\
\hline Вологодская область & 74,4 & 56,2 & 39,6 & 27,2 & 17,2 & высокий \\
\hline Калининградская область & 44,1 & 29,1 & 22,9 & 19,7 & 19,5 & средний \\
\hline Ленинградская область & 9,0 & 5,6 & 3,7 & 2,5 & 2,0 & высокий \\
\hline Мурманская область & 39,8 & 35,9 & 33,4 & 29,5 & 17,0 & высокий \\
\hline Ненецкий АО & 0,6 & 27,7 & 18,0 & 9,3 & 7,0 & высокий \\
\hline Новгородская область & 62,6 & 55,4 & 53,5 & 49,7 & 43,4 & средний \\
\hline Псковская область & 58,9 & 57,4 & 61,1 & 51,6 & 47,2 & низкий \\
\hline Республика Карелия & 75,0 & 69,5 & 70,8 & 43,8 & 36,9 & средний \\
\hline Республика Коми & 60,3 & 69,4 & 54,3 & 33,9 & 29,5 & высокий \\
\hline Санкт-Петербург & 3,4 & 2,9 & 6,8 & 5,2 & 4,7 & высокий \\
\hline
\end{tabular}

Составлено авторами по: [27, 31].

являются различными понятиями. Так, при сравнимых показателях долговой нагрузки Новгородской и Псковской областей, первая относится к субъектам федерации со средней долговой устойчивостью, а вторая признана регионом с низким уровнем долговой устойчивости. Рассмотрим особенности долга Псковской области (Таблица 6).

Как следует из анализа Таблицы 6, для государственного долга Псковской области прослеживается в целом тенденции его наращивания (при небольшом снижении в 2019 году) и суще- ственного изменения его структуры (Таблица 7).

Как следует из анализа Таблицы 7, структура долгового портфеля Псковской области существенно ухудшилась за рассматриваемый период: наблюдалось сокращение объемов бюджетных кредитов, которые замещались банковскими кредитами; до нуля уменьшился объем выданных государственных, не проводилась эмиссия субфедеральных облигаций, что связано со значительным объемом накопленных обязательств, превышающих собственные доходы субъекта (Таблица 8).

Таблица 6. Государственный долг Псковской области в 2015-2020 гг., млрд. руб.

\begin{tabular}{|l|c|c|c|c|c|c|}
\hline \multicolumn{1}{|c|}{ Показатель } & 2015 & 2016 & 2017 & 2018 & 2019 & 2020 \\
\hline Валовый региональный продукт, млрд. руб. & 135,2 & 145,5 & 151,5 & 164,3 & 197,1 & 166,7 \\
\hline Доходы бюджета, млрд. руб. & 22,6 & 25,8 & 26,8 & 31,6 & 36,0 & 41,8 \\
\hline $\begin{array}{l}\text { В т.ч. безвозмездные поступления, в млрд. } \\
\text { руб. }\end{array}$ & 9,4 & 10,8 & 10,7 & 13,9 & 17,7 & 22,9 \\
\hline $\begin{array}{l}\text { Доходы бюджета без учета безвозмездных } \\
\text { поступлений, млрд. руб. }\end{array}$ & 13,2 & 15 & 16,1 & 17,7 & 18,3 & 18,9 \\
\hline Доля доходов бюджета в ВРП, \% & 16,7 & 17,7 & 17,7 & 19,2 & 18,3 & 25,1 \\
\hline $\begin{array}{l}\text { Доля доходов бюджета в ВРП без учета без- } \\
\text { возмездных поступлений, в \% }\end{array}$ & 9,8 & 10,3 & 10,6 & 10,8 & 9,3 & 11,3 \\
\hline Расходы бюджета, млрд. руб. & 24,6 & 27,3 & 28,3 & 31,7 & 36,5 & 49,3 \\
\hline Объем государственного долга, млрд. руб. & 13,3 & 14,8 & 16,4 & 16,3 & 17,0 & 19,0 \\
\hline в том числе & & & & & & 0 \\
\hline Государственные ценные бумаги субъекта РФ & 0 & 0 & 0 & 0 & 0 \\
\hline $\begin{array}{l}\text { Кредиты от кредитных организаций, ино- } \\
\text { странных банков и международных финансо- } \\
\text { вых организаций }\end{array}$ & 7,6 & 9,4 & 10,2 & 11,7 & 14,2 & 15,1 \\
\hline $\begin{array}{l}\text { Государственные гарантии субъекта Россий- } \\
\text { ской Федерации }\end{array}$ & 0,6 & 0,6 & 0,5 & 0,3 & 0 \\
\hline Бюджетные кредиты & 5,1 & 4,9 & 5,6 & 4,2 & 2,8 & 3,9 \\
\hline
\end{tabular}

Составлено авторами по: [27, 28]. 
Таблица 7. Структура долгового портфеля Псковской области, 2015-2020 гг.,\%\%.

\begin{tabular}{|c|c|c|c|c|}
\hline & $\begin{array}{c}\text { Государственные цен- } \\
\text { ные бумаги субъекта } \\
\text { федерации }\end{array}$ & $\begin{array}{c}\text { Кредиты, полученные } \\
\text { от кредитных органи- } \\
\text { заций }\end{array}$ & $\begin{array}{c}\text { Государственные } \\
\text { гарантии субъекта } \\
\text { федерации }\end{array}$ & Бюджетные кредиты \\
\hline 2015 & $0 \%$ & $57 \%$ & $5 \%$ & $38 \%$ \\
\hline 2016 & $0 \%$ & $63 \%$ & $4 \%$ & $33 \%$ \\
\hline 2017 & $0 \%$ & $62 \%$ & $3 \%$ & $34 \%$ \\
\hline 2018 & $0 \%$ & $72 \%$ & $2 \%$ & $26 \%$ \\
\hline 2019 & $0 \%$ & $83 \%$ & $0 \%$ & $17 \%$ \\
\hline 2020 & $0 \%$ & $79 \%$ & $0 \%$ & $21 \%$ \\
\hline
\end{tabular}

Составлено авторами по: [27].

Таблица 8. Отношение госдолга и дефицита/профицита бюджета Псковской области к налоговым и неналоговым доходам, 2015-2020 гг.

\begin{tabular}{|c|c|c|c|c|c|c|c|}
\hline & 2015 & 2016 & 2017 & 2018 & 2019 & 2020 & $\begin{array}{c}\text { Поро- } \\
\text { говые } \\
\text { значения }\end{array}$ \\
\hline $\begin{array}{l}\text { Дефицит/профицит бюджета } \\
\text { субъекта, млрд. руб. }\end{array}$ & $-2,0$ & $-1,5$ & $-1,6$ & $-0,09$ & 0,4 & $-3,1$ & \\
\hline $\begin{array}{l}\text { Налоговые и неналоговые дохо- } \\
\text { ды, млрд. руб. }\end{array}$ & 1,6 & 1,6 & 1,7 & 1,7 & 1,7 & 1,9 & \\
\hline $\begin{array}{l}\text { Дефицит регионального бюдже- } \\
\text { та к налоговым и неналоговым } \\
\text { доходов, в \% }\end{array}$ & $-126,1$ & $-95,5$ & 91,8 & 5,5 & 23,9 & $-167,8$ & $<=15 \%$ \\
\hline $\begin{array}{l}\text { Государственный долг, в млрд. } \\
\text { руб. }\end{array}$ & 13,3 & 14,8 & 16,3 & 16,3 & 17,0 & 19,0 & \\
\hline $\begin{array}{l}\text { Объем госдолга к налоговым и } \\
\text { неналоговым доходам, в \% }\end{array}$ & 832,7 & 912,4 & 965,6 & 957,4 & 1014,4 & 1018,8 & $<=100 \%$ \\
\hline
\end{tabular}

Составлено авторами по: [27, 28].

Как показывает анализ данных Таблицы 8, ключевые показатели долговой устойчивости Псковской области существенно ниже установленных пороговых значений по обеим позициям, причем в 2015-2017 гг. пороговые значения были превышены более чем в 8 раз, что определяет необходимость существенной корректировки стратегии не только долговой, по всей социально-экономической политики развития области на среднесрочную и долгосрочную перспективу.

Если сравнить структуру долговых портфелей двух регионов с разным уровнем долговой устойчивости: Псковской области с низким уровнем и Республики Карелия - средним уровнем долговой устойчивости (Таблица 9), а также динамику ряда показателей их социально-экономического развития, которые непосредственно связаны с бюджетным финансированием (Таблица 10), то представляется возможным сделать следующие выводы.

Как следует из анализа данных Таблицы 9, структура долгового портфеля Республики Коми была более сбалансированной, чем у Псковской области, причем преобладал такой долговой инструмент, как субфедеральные облигации, которые в среднесрочном и долгосрочном аспекте являются более предпочтительными по сравнению с банковскими кредитами.

Сравнение динамики доли расходов бюджетов Республики Коми и Псковской области в региональных ВРП свидетельствует о разнонаправленных тенденциях по таким показателям, как образование, где наблюдается определенная стабильность, здравоохранение, где доля расходов имеет тенденцию к сокращению, социальная политика, где прослеживается тенденция роста расходов. При этом в приведенной структуре расходов в Республике Коми ведущую позицию занимает показатель «государственные инвестиции в основной капитал в\% к ВРП», составляющий по годам 17,0-36,6\%\% в отличие от Псковской области, где этот показатель находится в диапазоне 3,0-4,2\%, что свидетельствует о 
Таблица 9. Структура долговых портфелей Республики Коми и Псковской области, 2015-2020 гг.

\begin{tabular}{|c|c|c|c|c|c|c|c|c|c|c|c|c|}
\hline \multirow{2}{*}{ Статьи расходов } & \multicolumn{6}{|c|}{ Республика Коми } & \multicolumn{6}{|c|}{ Псковская область } \\
\hline & 2015 & 2016 & 2017 & 2018 & 2019 & 2020 & 2015 & 2016 & 2017 & 2018 & 2019 & 2020 \\
\hline $\begin{array}{l}\text { Государственные цен- } \\
\text { ные бумаги субъекта } \\
\text { федерации, в \% }\end{array}$ & 61,0 & 40,0 & 60,0 & 74,0 & 73,0 & 45,1 & 0 & 0 & 0 & 0 & 0 & 0 \\
\hline $\begin{array}{l}\text { Кредиты, полученные } \\
\text { от кредитных органи- } \\
\text { заций, в \% }\end{array}$ & 13,0 & 39,0 & 19,0 & 0 & 0 & 22,3 & 57,0 & 63,0 & 62,0 & 72,0 & 83,0 & 79,0 \\
\hline $\begin{array}{l}\text { Государственные } \\
\text { гарантии субъекта } \\
\text { федерации, в \% }\end{array}$ & 2,0 & 1,0 & 1,0 & 0 & 0 & 0 & 5,0 & 4,0 & 3,0 & 2,0 & 0 & 0 \\
\hline $\begin{array}{l}\text { Бюджетные кредиты, } \\
\text { в \% }\end{array}$ & 24,0 & 19,0 & 20,0 & 25,0 & 26,0 & 32,6 & 38,0 & 33,0 & 34,0 & 26,0 & 17,0 & 20,9 \\
\hline $\begin{array}{l}\text { Объем государствен- } \\
\text { ного долга, в млрд. руб. }\end{array}$ & 33,8 & 41,8 & 38,5 & 28,4 & 25,5 & 35,9 & 13,3 & 14,8 & 16,4 & 16,3 & 17,7 & 19,0 \\
\hline
\end{tabular}

Составлено авторами по [27].

Таблица 10. Динамика доли расходов к ВРП бюджетов Республики Коми и Псковской области, 2015-2019 гг.

\begin{tabular}{|c|c|c|c|c|c|c|c|c|c|c|}
\hline \multirow{2}{*}{ Статьи расходов } & \multicolumn{5}{|c|}{ Республика Коми } & \multicolumn{5}{|c|}{ Псковская область } \\
\hline & 2015 & 2016 & 2017 & 2018 & 2019 & 2015 & 2016 & 2017 & 2018 & 2019 \\
\hline Образование, в \% к ВРП & 4,6 & 4,4 & 4,1 & 4,1 & 4,3 & 5,0 & 4,7 & 5,7 & 4,6 & 6,0 \\
\hline Здравоохранение, в \% к ВРП & 2,4 & 2,0 & 0,9 & 1,0 & 1,3 & 3,4 & 2,8 & 1,6 & 1,6 & 2,2 \\
\hline $\begin{array}{l}\text { Социальная политика, в \% к } \\
\text { ВРП }\end{array}$ & 2,1 & 2,3 & 3,3 & 3,0 & 3,0 & 3,8 & 3,3 & 5,5 & 4,7 & 5,3 \\
\hline $\begin{array}{l}\text { Государственные инвести- } \\
\text { ции в основной капитал, в \% } \\
\text { к ВРП }\end{array}$ & 32,2 & 36,6 & 23,3 & 20,5 & 17,0 & 3,0 & 3,7 & 4,2 & 3,7 & 3,0 \\
\hline
\end{tabular}

Составлено авторами по: [31, 32].

том, что бюджет Псковской области не обеспечивает экономического развития территории, а, следовательно, и в перспективе устойчивости финансовой системы региона.

Заключение. Долговая политика субъекта федерации является важным условием обеспечения выполнения региональным бюджетом своих основных функций, а также фактором обеспечения устойчивости всей региональной финансовой системы. При определении направлений совершенствования долговой политики необходимо ориентироваться как на ключевые показатели и индикаторы, которые задаются федеральным законодательством, так и учитывать те цели социально-экономического развития, которые определяются территориальными особенностями. Одним из важнейших направлений долговой политики является сбалансирование долгового портфеля по основным долговым инструментам, что предполагает необходи- мость активного взаимодействия с финансовым рынком. Субфедеральные облигации являются эффективным инструментом привлечения заемного капитала и регионам необходимо повышать его долю в своих долговых портфелях. Хоть данный удельный весь государственных ценных бумаг по СЗФО в последние годы растет, это достигается в основном за счет крупных выпусков отдельных регионов, таких как Санкт-Петербург или Республика Коми, остальные субъекты редко проводят эмиссию. Для регионов СЗФО проблема совершенствования долговой политики носит не только теоретический, но и практический аспект, поскольку общий долг регионов СЗФО имеет тенденцию к росту, а следовательно, необходимо оптимизировать затраты на управление долгом, что предполагает целесообразность оценки эффективности использования долговых инструментов не только в краткосрочном, но и долгосрочном аспекте. 


\section{Библиографический список}

1. Бюджетный Кодекс Российской Федерации. Утв. 31 июля 1998 года № 145-Ф3.- URL: http://www.consultant. ru/document/cons_doc_LAW_19702/.

2. Об утверждении Правил проведения оценки долговой устойчивости. Постановление Правительства Российской Федерации от 04.03.2020 № 227.- URL: http://www.garant.ru/doc/maingarant.ru.

3. Рекомендации по проведению субъектами Российской Федерации ответственной заемной/долговой политики. Рекомендации Минфина России от 18 декабря 2015 г.-URL: https://minfin.gov.ru/

4. Основные направления государственной долговой политики Российской Федерации на 2017-2019 гг. Документ Министерства финансов Российской Федерации. - URL: https://minfin.gov.ru/

5. Волынская О.А. Понятие долговой политики и критерии оценки ее эффективности. // Аваль. - 2006. - № 4 . C. 117-119.- Текст: электронный. - URL: https://www.elibrary.ru/item.asp?id=11609911.

6. Ермакова Е.А. Система качественных критериев для оценки эффективности долговой политики субъекта РФ // Финансы и кредит.- 2013. Т. 19, вып. 46.- С.- Текст: электронный._ URL: https://www.elibrary.ru/ item.asp?id=20811316.

7. Солдаткин С.Н. Эффективность региональной долговой политики через призму инвестиционной активности. // Региональная экономика: теория и практика. - 2015. - № 30 (405). - С. 46-57- - Текст: электронный.- URL: https://www.elibrary.ru/item.asp?id=23907157.

8. Genorio Hana. General government debt sustainability in Slovenia / // Bank of Slovenia Analysis \& Research Department.- Текст: электронный._URL: https://bankaslovenije.blob.core.windows.net/publication-files/nov_ genorio57_88.pdf.

9. Кадзаева И. Т. Долговая политика бюджета региона и ее изменения //Terra economicus. 2012.- T. 10. № 2. Ч. 2.-C. 158-160 - Текст: электронный. - URL: https://www.elibrary.ru/item.asp?id=17865578.

10. Кудрявцева С. А. Государственный долг субъекта федерации: понятие, виды и формы долговых обязательств. // Финансы и управление.-2016. - № 1. С. 100-116.

11. Сангинова, Л.Д. Эффективная долговая политика субъектов Российской Федерации: теория и практика // Экономика. Налоги. Право.-2018. - № 1.-96-105.

12. Солдаткин С.Н. Оценка эффективности государственной региональной долговой политики (на примере субъектов РФ, входящих в ДФО) // Вестник Хабаровской академии экономики и права.- 2019.- № 1.- С. 59-60.- Текст: электронный. -https://elibrary.ru/item.asp?id=38238794.

13. Королева М.Л. Государственный долг субъектов Российской Федерации: состояние и проблемы. // Вестник Волжского университета им. В.Н. Татищева.-2019.- № 3. Том. 2.- С. 179-186

14. Ларина О. И., Морыженкова Н.В. Субфедеральные и муниципальные заимствования в России: содержание, источники, зарубежный опыт и перспективы развития // Региональная экономика: теория и практика.2016. - № 1 (424). - С. 70-88.

15. Коречков Ю.В. Долговая устойчивость региона как основа его стратегического развития // Социальнополитические исследования.-2020.- № 2 (7).- С. 81-91.

16. Основные направления государственной долговой политики Республики Карелия на 2020 год и на плановый период 2021 и 2022 годов.- Текст: электронный.- URL: http://minfin.karelia.ru/assets/gosdolg/ dolgovaya-politika-na-2020-god.docx.

17. Основные направления государственной долговой политики Республики Коми на 2021 год и плановый период 2022 и 2023 годов - Текст: электронный. -https://minfin.rkomi.ru/uploads/documents/rasp_prav_va_ rk_09_12_2020_382_r_dolgovaya_politika_2021_2023_pdf_2020-12-14_10-10-57.pdf.

18. Основные направления государственной долговой политики Архангельской области на 2020 год и на плановый период 2021 и 2022 годов - Текст: электронный.- URL: https://www.regulation.dvinaland.ru/docs/ anti-corruption/1308/.

19. Бюджет Ненецкого автономного округа на 2021 год и на плановый период 2022 и 2023 годов - Текст: электронный.- URL: https://rg.ru/2020/12/21/nao-zakon232-reg-dok.html.

20. Основные направления бюджетной и налоговой политики Вологодской области, долговой политики Вологодской области на 2020 год и плановый период 2021 и 2022 годов - Текст: электронный. - URL: https:// vologda-oblast.ru/dokumenty/2126103/.

21. Об утверждении долговой политики Калининградской области на 2020 год и плановый период 2021 и 2022 годов. Постановление - Текст: электронный.-URL: http://docs.cntd.ru/document/561620410.

22. Областной бюджет Ленинградской области - Текст: электронный. - URL: http://budget.lenreg.ru/budget/ num/region/current/. 
23. Основные направления государственной долговой политики Мурманской области на 2020 год и на плановый период 2021 и 2022 годов - Текст: электронный._URL: https://minfin.gov-murman.ru/upload/iblock/01e/ DOLGOVAYA-POLITIKA_2020_2022.pdf.

24. Обутверждении основных направленийдолговой политики Новгородской области на 2020 год и на плановый период 2021 и 2022 годов.- Текст: электронный.- URL: https://www.novreg.ru/upload/iblock/19c/25773233. pdf.

25. Об утверждении Основных направлений долговой политики Псковской области на 2021 год и на плановый период 2022 и 2023 годов. Распоряжение Правительства Псковской области от 18 декабря 2020 года N 696-p - Текст: электронный. - URL: http://docs.cntd.ru/document/462725453.

26. Основные направления долговой политики Санкт-Петербурга на 2020 год и на плановый период 2021 и 2022 годов - Текст: электронный.- URL: https://www.gov.spb.ru/static/writable/documents/2019/09/23/Ocновные_направления_долговой_политики_20-22.pdf.

27. Объем и структура государственного долга субъектов Российской Федерации и долга муниципальных образований - Министерство финансов Российской Федерации - Текст: электронный. - URL: https://minfin. gov.ru/ru/perfomance/public_debt/subdbt/.

28. Отчет об исполнении областного бюджета. Министерства финансов Российской Федерации.-URL: https:// minfin.gov.ru/ru/perfomance/public_debt/subdbt/.

29. Выпущенные на внутреннем рынке долговые ценные бумаги. Банк России.- URL: https:/cbr.ru/statistics/ macro_itm/sec_st/.

30. Об утверждении Правил проведения оценки долговой устойчивости. Постановление Правительства Российской Федерации от 04.03.2020 № 227 URL: https://minfin.gov.ru

31. О классификации субъектов Российской Федерации по группам долговой устойчивости. 01.10.2020 // https://minfin.gov.ru/ru/document/?id_4=131626-o_klassifikatsii_subektov_rossiiskoi_federatsii_po_gruppam_ dolgovoi_ustoichivosti.

32. Территориальный орган Федеральной службы государственной статистики по Псковской области - Текст: электронный. - URL: https://pskovstat.gks.ru/.

33. Территориальный орган Федеральной службы государственной статистики по Республики Коми - Текст: электронный. - URL: https://komi.gks.ru/folder/67038/document/67039?print=1. 